\title{
Chasing the city that cannot stop: Exploring transportation and urban co-development in São Paulo's history
}

\author{
Adriano Borges Costa (corresponding \\ author) \\ Massachusetts Institute of Technology and \\ Arq.Futuro Cities Lab/Insper \\ abcosta@mit.edu \\ Ciro Biderman \\ Fundação Getulio Vargas \\ ciro.biderman@fgv.br
}

\author{
Christopher Zegras \\ Massachusetts Institute of Technology \\ czegras@mit.edu
}

Abstract: We present a historical analysis of transportation and urban development in Sáo Paulo (Brazil), attempting to discern Granger causal effects using historical land-use and transportation data from 1881 to 2013 . Our results align with the hypothesis commonly stated in the literature about the relevance of road transportation in São Paulo's peripheral urban expansion during the twentieth century. We find, however, more complex relationships, and changes in them, over time. Over the entire 130 years, we find that urban expansion and road development pushed and pulled each other, in a somewhat "orderly" way. On the other hand, while roads are not linked to densification, we find that mass transit infrastructure did lead to building densification. Distinguishing among distinct periods adds further insights. Examining São Paulo’s "streetcar era" we find joint development of streetcar lines and urban expansion - evidence of joint development consistent with "streetcar suburbs." Streetcars also led to building densification during this early period. In subsequent decades, up until the mid-1970s, mass transit investments are virtually non-existent and road transportation essentially chases urban expansion, not vice versa. Finally, the last four decades reveal a return to "orderly" patterns of road expansion and urbanization but no evidence of mass transit infrastructure's effects on urbanization or densification. The analysis illustrates how transportation investment choices have important consequences for urban growth, exerting long-lasting influences on its urban form.

\section{Article history:}

Received: February 15, 2021

Received in revised form: May

12,2021

Accepted: May 18, 2021

Available online: October 6, 2021

\section{$1 \quad$ Introduction}

At the turn of the twentieth century, Sáo Paulo was inhabited by less than 250,000 people and its main transportation system was based on animal-drawn streetcars. At the same time, London already had a subway system for its more than 6 million inhabitants and New York, home to around 3.5 million people, was beginning construction of its subway system. Today, however, the São Paulo metropolitan region is the world's fourth most populous urban area, larger than the metropolitan areas of London or New York (United Nations, 2019). In other words, São Paulo was transformed from a medium city

Copyright 2021 Adriano Borges Costa, Christopher Zegras \& Ciro Biderman http://dx.doi.org/10.5198/jtlu.2021.1969

ISSN: 1938-7849 | Licensed under the Creative Commons Attribution - Noncommercial License 4.0

The Journal of Transport and Land Use is the official journal of the World Society for Transport and Land Use (WSTLUR) and is published and sponsored by the University of Minnesota Center for Transportation Studies. 
to a great metropolis in a single century. While London took 210 years to grow from 1 million to 8 million people and New York did the same in 110 years, São Paulo took just 40 years. The pace of the city's urban and economic growth originated the popular motto: "Sáo Paulo cannot stop." The slogan, used by politicians to emphasize the relevance of maintaining investment in the metropolis' economic growth, also characterizes the inability to contain the city's unbridled and disorderly urban growth, in which transportation has played a central role.

The inextricable links between transportation and urban development help explain many of the prevailing patterns of the world's main urban centers, including New York's skyscrapers, London's suburbs, Rome's narrow streets, and São Paulo's poor peripheral settlements. Railway routes played a key role in developing São Paulo's Brás neighborhood and Boston's "streetcar suburbs," while Robert Moses's highways shaped New York's Long Island. To be sure, a range of factors ultimately influence the form our cities take, but the land use-transport connections cannot be denied. The density of homes and firms, for example, determines potential public transport ridership. The connectivity provided by roads and rail influences the attractiveness of areas where households and companies make locational choices. From these mutually dependent relationships between transportation and land development our central, quintessential chicken-and-egg, question emerges: does transport infrastructure lead or follow urban development? In other words, which came first, urbanization or transportation?

We seek to answer this question within the city of São Paulo, Brazil. Existing literature highlights the central role that road transport (mainly buses) played in allowing the city's peripheral expansion, although systematic empirical evidence of this effect is weak. This paper briefly reviews São Paulo's transportation and urban development history and compiles urbanization and transportation infrastructure development data from over a century of the city's history to empirically examine how roadway and public transit development has pushed and been pushed by urban expansion and building densification.

The remainder of this paper consists of five sections. The following section discusses analyses of the chicken-and-egg dilemma in a range of cities from the global north. The third section consists of a historical overview of the joint transport/land-use development of São Paulo, and presents our hypotheses. The fourth section presents the data, our analytical approach, and results. The final section discusses the implications and concludes.

\section{The chicken-and-egg dilemma in urban transportation}

The modern metropolis has been shaped by the intimate relationship between land development and transportation technologies. In the historical context of metropolitan USA, for example, Muller (2004) traces how the prevailing mobility technologies of the time map to distinct patterns of urbanization, from the small monocentric cities of the walking/horsecar era up to the 1890s, to the emergence of radial suburbs during the electric streetcar era of 1890-1920, the first auto-oriented residential and commercial developments during the recreational auto era from 1920-1945, and the sprawling multi-centric metropolises of the postwar Interstate Highway era. Which comes first, however, urbanization or transportation, and how do these influence each other over time? These questions have more than historical, or purely academic, relevance. As transportation infrastructures influence the location, pace, and form of urban development, these infrastructures can thus impact the subsequent demands for transportation, including the distribution, distances, routes and modes of travel. Ultimately, the performance of transportation infrastructure and services and the attractiveness of urban development projects are at stake, with important implications for public finance (e.g., property taxes), intra-metropolitan integration (e.g., suburban versus center city vitality) and overall quality of life (e.g., congestion, pollution).

The influence of urban transportation on urban development has long been studied. Reviewing 
over 30 years of empirical analysis, Boarnet and Haughwout (2000) found evidence generally suggesting that metropolitan highways influence land prices, population and employment changes in the USA. A number of scholarly papers have reviewed the large body of previous empirical research on transportation and land-development and land-value effects (e.g., Badoe \& Miller, 2000; Boarnet \& Haughwout, 2000; Cervero \& Seskin, 1995; Giuliano, 2004; Huang, 1996; Knight \& Trygg, 1977; Martínez \& Viegas, 2009; Ryan, 1999) and studies on this topic often focus on short- and medium-term real estate appreciation (Debrezion, Pels, \& Rietveld, 2007; Mohammad, Graham, Melo, \& Anderson, 2013). The research differs in empirical contexts, analytical approaches, types of properties analyzed, types of infrastructures and services considered, etc. Ryan (1999) notes that first-generation highway studies (1950s and 1960s) primarily employed before-and-after analyses, while subsequent highway and nearly all transit analyses (beginning in the 1960s) applied varying forms of econometric modeling. Recent improvements in geographical information systems and wider data availability from urban areas are expanding the body of evidence on longer-term impacts of transportation on urban development, land use, population and employment densities (Kasraian, Maat, Stead, \& van Wee, 2016). As Kasraian et al. (2016) note, however, studies of potential bidirectional relationships between transport and land use remain scarce but are necessary to understand which leads and which follows, and how this might differ over time.

Empirical analyses aiming to untangle the land development-transportation links face the classic causality challenge: how can we know if land development (or price) follows transportation investments, or leads them? Relevant techniques include before-and-after studies and time-series analysis, including repeat sales approaches (e.g., McMillen \& McDonald, 2004) or instrumental variables (e.g., BaumSnow, 2007). Another approach entails Granger causality models, as King (2011), Levinson (2008a), and Xie and Levinson (2010) use to assess whether population or transit infrastructure came first, in long-term analyses of New York, Twin Cities (Minneapolis-St. Paul) of Minnesota, and London, respectively. King (2011) found that in New York the subway system did not lead to building densification in surrounding areas, and instead was built in areas which already had a strong commercial presence and were previously well-served by transit services. Xie and Levinson (2010) present some evidence that streetcar network development between 1900 and 1930 preceded residential real estate development within 800 meters of a line in Minneapolis-St Paul. Levinson (2008a) used demographic data from 1871 to 2001 and information about the inauguration of train and subway stations in London to show that rail transport contributed to the densification and urban development of peripheral and suburban regions but that, in the urban core, transport infrastructure was established in already densified areas.

In their review of long-term (10 to 90 years) impacts of transportation networks on land use (land cover, population or employment density, or development type), Kasraian et al. (2016) examine 22 studies from the USA (12 for roads, 5 for rail, and five for road and rail), 21 from Europe (3 for roads, 10 for rail, and 8 for road and rail) and 6 from Asia ( 2 for roads and 4 for roads and rail). While shorterterm analyses exist in the Latin American context (e.g., Guerra, 2014; Rodríguez \& Mojica, 2009), we could find no historical analysis of urban transportation (road and rail) and land development in the region. Following King (2011) and Levinson (2008a), we use Granger Causality analysis of São Paulo’s historical data on transportation and urban development to test which came first, urban development or urban transportation (or if they were parallel), and how this relationship has varied over time and types of infrastructures.

\section{Transportation and urban development in São Paulo}

Between 1867 and 1875, when three railroads crossing the city were constructed to meet the shipping 
demands of the region's growing coffee economy, São Paulo was home to fewer than 20,000 people and was highly isolated from most of Brazil (Langenbuch, 1971, pp. 25-36). São Paulo quickly became a regional transportation hub and the city's economy began developing around financial and trade services related to the vast amounts of coffee passing through its still-limited urban area. Even though São Paulo's regional connectivity vastly improved with the railways, its intra-urban transportation infrastructure remained modest (Langenbuch, 1971, p. 98).

In 1900, a Canadian company, popularly known as "Light," launched the city's first electric streetcar route, initiating what would become São Paulo’s first regular mass transportation system (Silva, 2015, ch. 2). Light had an exclusive license to operate streetcars in the city and was responsible for service planning and investments to maintain and expand the system quite freely of public regulations. ${ }^{1}$ Light's deployment of a new streetcar route required a financial equilibrium, in which the potential number of current and future fare-paying clients balanced the costs of establishing and operating the route. On its own, such an approach typically does not provide incentives for transit operators to invest in still-underdeveloped areas and bring transportation first.

Besides the transit service, Light was also the single supplier of electricity and telephone utilities for the city's households and growing manufacturing sector (Rolnik, 1995, p. 241). Together, these made the company a convenient partner in any real estate business. Light could expect some cross-gains when co-deploying these services. Thus, Light likely had cross-interests in generating real estate appreciation in a "streetcar suburb" (Warner, 1978) model of development. Indeed, the company had its own real estate strategy to acquire properties in anticipation of future returns (Rolnik, 1995, p. 226; Eletropaulo, 1986a), and several of its directors served on the Board of Directors of City Company, a real estate developer that owned 37\% of urban land in São Paulo in 1912 (Rolnik, 1995, p. 228-229).

Map 1 shows that in 1929 the streetcar lines nearly entirely overlapped with the city's urban footprint and even extended beyond the borders to reach some isolated new neighborhoods. ${ }^{2}$

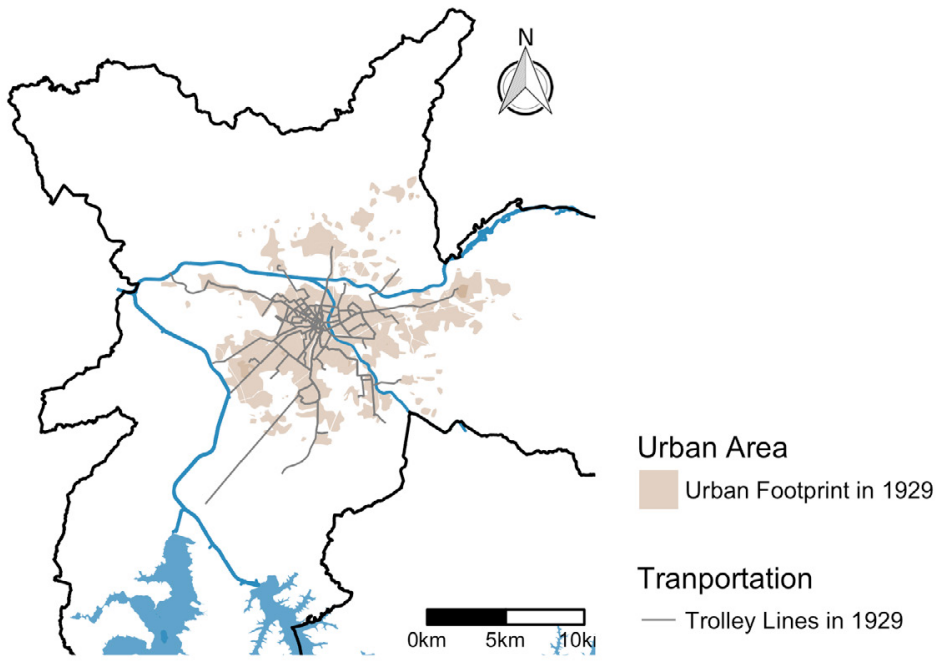

Map 1. Urban area and streetcar lines in São Paulo, 1929

Source: The authors with streetcar lines geocoded from Stiel (1978) and urban footprint polygons from EMPLASA (2002)

\footnotetext{
1 The exception was the control over the fare values, which were frozen in 1909 by the municipal government.

${ }^{2}$ Two streetcar extensions toward the south merit attention. The smaller stretch is a streetcar line that substituted a steam tramway opened in 1885, mostly to transport meat from a new municipal slaughterhouse and wood and food produced in the southern region known as Santo Amaro. The passengers on this south strand became relevant only after the line was electrified and integrated into the streetcar system in 1912. The steam services were disactivated and only the initial stretch was electrified. The longer straight line was built in 1913 to reach the settlement of Santo Amaro (STIEL, 1978, ch. 4).
} 
The number of routes and streetcars in São Paulo increased constantly until the second half of the 1920s (Stiel, 1978, ch. 7), when São Paulo approached 1 million inhabitants, with around 500 streetcars serving 200 million trips per year (Mendes, 1992, p. 59). Sáo Paulo's urban area also expanded by almost 700\% between 1897 and 1929, while its manufacturing base grew rapidly and its population growth was fueled by constant and increasing immigration, first from Europe and later from the Brazilian northeast (Caldeira, 2000, ch. 6). Urban infrastructure struggled to keep up with the rapid growth and changing urban conditions.

The incipient energy production infrastructure could not keep pace with the city's growth, leading to many energy crises. To avoid impacts on manufacturing and household consumption, Light constantly opted to reduce its operational fleet of electric-powered streetcars (Stiel, 1978, p. 24), and small private buses began to circulate independently and informally around the city (Silva, 2015, pp. 74-76). At the same time, streetcar fares remained frozen, despite inflation, reducing the fares' real value by twothirds compared to 1909 prices (Rolnik, 1995, p. 165). The streetcar system, which had been Light's most profitable service during its first years of operation, became less attractive (Mendes, 1992). The system became outdated and operational problems created daily headaches for riders (Eletropaulo, 1986b).

By the 1920s, São Paulo began experiencing urban problems similar to the ones it faces today: traffic congestion, lack of parking, floods, informal settlements, and urban disorder. Under pressure to improve and expand its streetcar network, Light proposed in 1927 that the city government extend its transit service contract under new terms in return for making considerable new investments to remodel the system, as part of its "Integrated Transportation Plan" (Silva, 2015, ch. 4). The plan proposed to increase the number of streetcars and expand the streetcar network by $50 \%$, operate a unified bus service integrated with the streetcars, deploy underground sections in the city core, implement an express tram system with segregated trunk lines, and expand the feeder lines with streetcars and buses (Eletropaulo, 1986b). To implement the plan, Light called for controversial fare increases and a monopoly on streetcar and bus services (Eletropaulo, 1986b; Vitte \& Imaeda, 2007).

At the same time, another extensive plan was under debate: to build avenues from the city center to the suburbs and redesign the commercial streets in the city core (called the "Avenue Plan"). The differences between the Avenue Plan and Light's Integrated Transportation Plan sparked furious debate among local decision makers, real estate business interest groups, the press, and commuters (Silva, 2015, ch. 4-5). Technical reports and newspaper articles for and against Light's Plan were published. Despite Light's local political connections and support for its plan from transportation and urban planning experts, the company faced criticism by the media and daily users due to the poor commuting conditions (Silva, 2015, ch. 4).

Eventually, the political and technical elites of the city decided that streetcars were less flexible, more expensive, and unable to support urban decentralization. At this point in time, urban concentration was considered undesirable and high population density was seen as a sanitary, social, and moral problem responsible for the spread of illnesses and vagrancy (Kowarick \& Frúgoli, 2016, p. 125). In 1930, a coup resulted in a pro-industrial nationalist dictatorship, characterized by a centralization of powers at the national level. The automobile industry became a centerpiece of the national development strategy in the next decades, with road transportation investments following suit. In São Paulo, this meant the adoption of the Avenue Plan, created by the engineer Prestes Maia. While initially implemented in the early 1930s, the Plan gained momentum when Maia was first named mayor of São Paulo (1938-45).

Meanwhile, Light's Plan was abandoned and the streetcar system decayed, gradually replaced by bus services. The number of buses in circulation increased from between one and two hundred in 1926 to three thousand by 1958 (Stiel, 1978). In 1948, streetcars accounted for $52.2 \%$ of total public transit trips; by 1966 this number fell to $2.4 \%$. The Avenue Plan facilitated the rapid increase in bus services, opening new frontiers for city expansion. Furthermore, producing a series of radial avenues from the 
center to the suburbs, which required considerable demolition and relocation, the plan remodeled the central region. According to Caldeira (2000, p. 219), by favoring roads and buses over streetcars, the plan "made possible the expansion of the city toward the periphery."

From the 1940s until the late 1960s, the implementation of the Avenue Plan (with various adjustments including contributions by Robert Moses) and the expansion of bus services dominated Sáo Paolo's transportation investment agenda. Car use was limited to wealthy families (Stiel, 1978, p. 1139 ), with the vast majority of poor and middle-income individuals using public transit for their daily commute to work (91.2\% of these trips in 1966; Velze, 1968). Only after the 1970s did car ownership become widespread among the Brazilian middle class'; in 1977, among families below median income, buses still accounted for about $90 \%$ of public transit trips and $71 \%$ of motorized trips (Metrô, 1977). In short, poor families' commuting during this period was almost exclusively by bus (Graph 1).

$50 \%$ POOREST

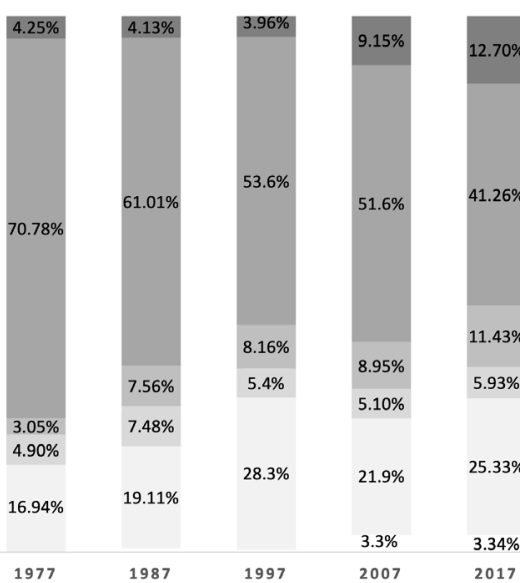

$50 \%$ WEALTHIEST

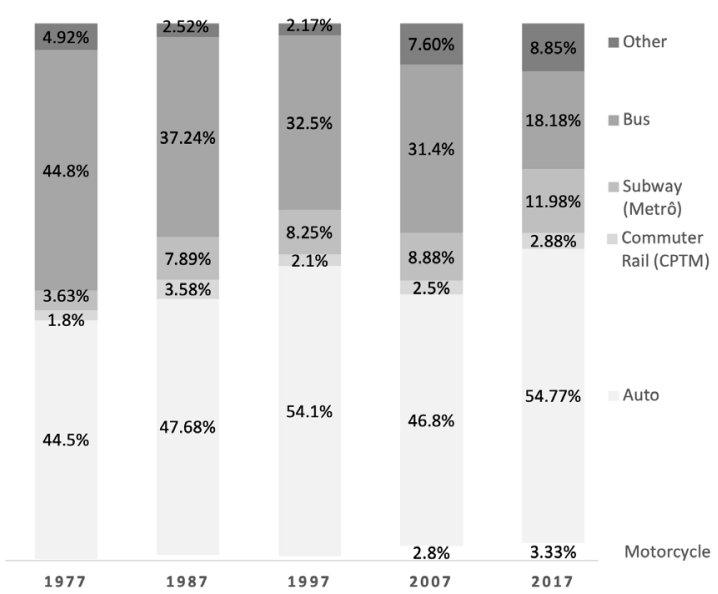

Graph 1. Changes in mode share and differences between the 50\% poorest and wealthiest in the Metropolitan Region of São Paulo-1977 to 2007

Source: The authors, using data from Metrô $(1977,1987,1999,2008,2019)$

If the city grew significantly prior to 1940, its growth exploded across its borders in a vast process of peripheral expansion in the following decades. Its urban area increased more than 1,220\% between 1929 and 1980. At the same time, neither the government nor the private market could meet the demand for low-cost housing; with no alternative, the low-income population self-built houses in areas far from the city center, without infrastructure, where land was inexpensive (Bonduki \& Rolnik, 1979; Caldeira, 2000, ch. 6). In the 1940s and 1950s the popular motto "São Paulo cannot stop" emphasized its promising future; in 1972, when the first master plan in São Paulo was approved, the mayor recognized the city's unbridled and disorderly urban growth and stated that "São Paulo must stop" (Somekh, 2014, p. 36). Under-regulated and under-serviced peripheral settlements drove urban dispersion (Caldeira, 2000, ch. 6; Rolnik, 1995), leading to profound socio-spatial inequality (Bonduki \& Rolnik, 1979).

Investments in mass public transit only resumed in 1968 with the start of construction of São Paulo's first stretch of subway, which began operations in 1974. By this time, São Paulo was a large metropolis, and its urban area had already expanded beyond its borders. The series of maps combined

3 In 1950, there were 63,000 motor vehicles in the city of São Paulo (Caldeira, 2000, p. 228), the equivalent of 29 vehicles per 1,000 inhabitants, a small fraction of today's value: 212/1,000 in 2017 (Metrô, 2019). 
on Map 2 shows how the urban footprint evolved from Light's urban rail and subway plan proposed in the 1920s to the 1968 subway plan. The map also includes a plan proposed by technicians of the Paris Subway, who were hired in 1947. In the first plans, proposed lines were to reach or approach the city limits, but over time the city sprawled while the planned transit networks only covered already urbanized areas. The final map shows the subway network as of 2013, demonstrating that only some of the planned lines were, in fact, implemented more than 30 years later.

\section{$1927 / 1929$}

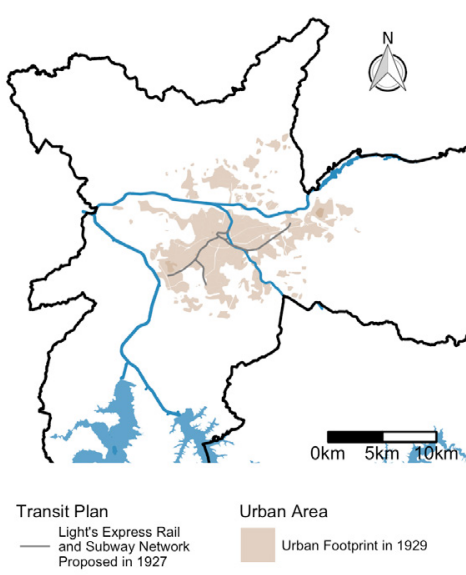

$1968 / 1974$

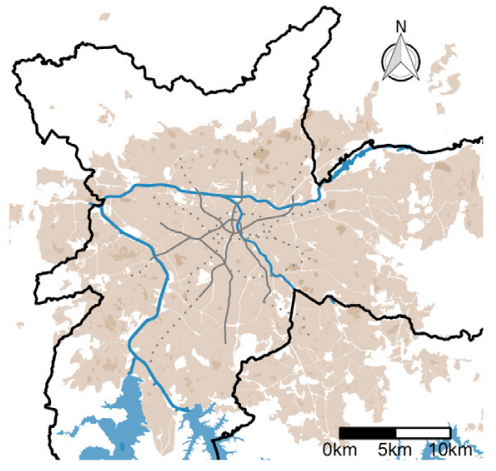

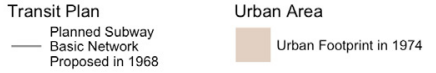

$1947 / 1949$

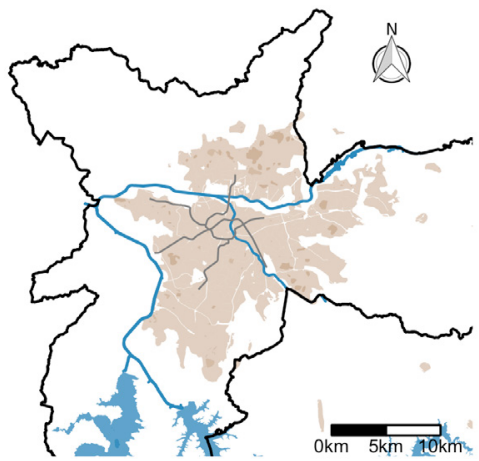

Transit Plan

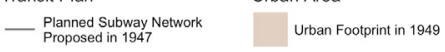

2013

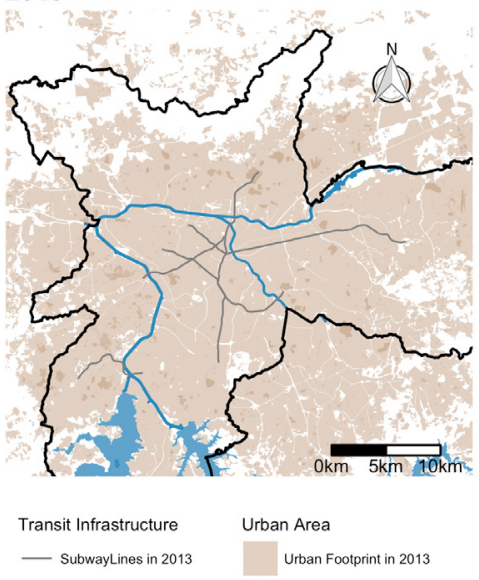

Map 2. Selected mass transit routes proposed over the history of São Paulo and subway lines running in 2013

Source: The authors with transit plans GIS files from Lisbôa (2019), subway lines in 2013 from GeoSampa, and urban footprint polygons from EMPLASA (2002)

In 1980, São Paulo was home to around 8.5 million people, with other cities in the metropolitan area accounting for another 4 million people. Over the following decades, the city's population growth rates reduced drastically: from an annual average of $4.75 \%$ between 1940 and 1980 to $0.94 \%$ from 1980 to 2010. During the latter period, Sáo Paulo expanded its nascent subway system and modernized its commuter rail services, including the construction of new stations. Several new bus corridors were also deployed, especially during the 2000s. At the end of 2017, the São Paulo metropolitan region's 
high-capacity transit infrastructure comprised 81.1 kilometers of subway lines (with 71 stations), 273 kilometers of commuter rail ( 94 stations) and 168 kilometers of bus corridors. These efforts to improve public transit service have not, however, proved sufficient to reverse the long-term trend of increasing car use (see Graph 1).

Caldeira (2000, ch. 6) claims that São Paulo’s peripheral urban growth was based on road transportation and the expansion of bus services. However, the simple temporal correlation between urban expansion, investments in road infrastructure, and bus fleet growth is not enough to validate this claim. Did new radial avenues and expanded bus services reach undeveloped areas, stimulating outskirt settlements? Or, were the roads and services gradually expanded to areas which had previously been occupied, responding to political pressure from the new residents? In this paper, we work with data on road infrastructure and mass-transit investments, among other datasets, to offer detailed empirical evidence on how transportation infrastructure development interacted with São Paulo's urban growth patterns, a gap in the literature that deserves more attention.

\subsection{Hypotheses}

São Paulo's rapid expansion and the complex development of its transportation system raises the question of whether urban expansion led transportation network growth, or vice versa. Which came first? Three hypotheses can be derived from this question. The first is the "reactive transportation hypothesis": transportation followed urban expansion and densification; in other words, transportation investments reacted to urbanization, responding to increased demand for transportation and local political pressure. The second is the "leading transportation hypothesis," which is the opposite of the first: urban expansion or densification follows transportation infrastructure investments in previously under-developed areas.

These two opposing hypotheses result from different kinds of incentives. Transportation leading urbanization has few apparent political incentives, as it will not translate into short-term votes or political support; still, important financial players (e.g., landowners, speculators) may have much to gain (and influence) from transportation investment in remote areas. On the other hand, transportation reacting to urbanization, through investments in already built-up areas, are considerably more expensive (Glaeser $\&$ Ponzetto, 2017). In other words, it can be cheaper to invest in transport prior to urban development and densification rather than react to urban development and invest afterwards. However, the latter strategy would require that transportation planners reasonably forecast where development will take place and can act in advance of it.

The third hypothesis is what Levinson (2008b) calls the "orderliness hypothesis": with transportation built concurrently with urbanization. This hypothesis assumes planning capacity to deploy transportation infrastructure in concert with urban development or densification. The government would benefit from the financial savings of building in areas that are not yet consolidated while simultaneously producing a land development-inducing effect, generating more ridership and fare revenues. At face value, this third hypothesis represents a "rational government," investing concurrently with new developments.

Although we have referred to "transportation investments," in general, the infrastructure type matters. Relative to mass transit infrastructure, roadway construction typically requires less investment and lower maintenance costs and offers greater flexibility. The higher costs of deploying and maintaining urban rail and dedicated bus-priority systems requires more planning and involves more risk. As the brief history above shows, different transportation modes played different roles throughout São Paulo's urban development. Thus, the relationship between transportation and urban development may vary according to the prevailing transport mode and the period of analysis. It may also vary depending on the kind of urban development: urban expansion, with the city advancing over previously non-urbanized 
areas; and/or, urban densification based on building upwards.

From existing literature and São Paulo's urban development background, a priori hypotheses for the different transport infrastructures in different periods are somewhat ambiguous. For roads and São Paulo's urban expansion, the "leading transportation hypothesis" seems to be aligned with the literature highlighting the central role of road transportation in contributing to peripheral urbanization. This relationship should intensify in the 1930s, when the city started to grow rapidly based on immigration, and the Avenues Plan began to be implemented and the bus system expanded. For mass transit, expectations are less clear. Urban rail investments involve more costs and risks, so we might expect that such investments will be made in a more "rational" and planned manner, following the "orderliness hypothesis." Over time in São Paulo, however, various mass transit investment plans have not been implemented, raising doubts about the government's ability to act as expected and take advantage of "joint" transportation and urban development. Mass transit should intensify building densities in central areas where land prices are high, but could also intensify expansion in an "orderly" "streetcar suburb" model during the Light era. This existing ambiguity regarding the three possible hypotheses makes clear the need for empirical investigation of transportation and urban development in the São Paulo context.

\section{$4 \quad$ Empirical analysis}

Our empirical strategy uses Granger causality models to explore transportation and urban development, assessing whether expansions in the road and mass transit networks led, followed, or were concurrent with urban development and building densification over different periods of São Paulo's history. If urbanization preceded investments in transportation infrastructure, we have evidence for the first hypothesis; if transportation infrastructure led increases in population density, the evidence supports the second hypothesis; evidence of bi-directional Granger causality supports the third, "orderliness" hypothesis.

\subsection{Data}

We compiled historical Geographic Information System (GIS) data to depict how land use and transportation networks evolved throughout Sáo Paulo's history. By working with raster and vector data, the boundaries of the geographical units of analysis could be defined according to the research requirements. We used a grid of square cells measuring $2 \mathrm{~km}$ on each side ${ }^{4}$ to calculate the following four metrics to represent the urban and transportation development in each cell $i$ at time $t$.

Urban Development Variables $\quad U r b_{i, t}$

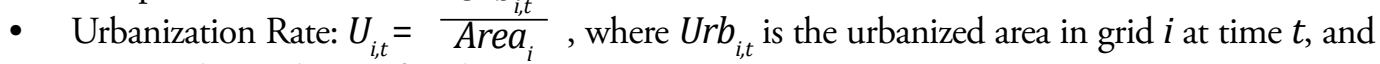
Area $_{i}$ is the total area of grid $i$.

- $\quad$ Number of buildings with more than 3 floors: $N_{i, t}$

Transportation Development Variables

- Mass transit network length: $\operatorname{Tnt}_{i, t}$

- $\quad$ Road (highways and avenues) network length: $R n t_{i, t}$

${ }^{4}$ We adopted a square grid as described in King (2011). To define the cell dimensions, we tested sizes ranging from one to four kilometers and observed the results from the models described in the next section. The smaller the cell area, the less statistically significant local effects are, and the more significant the effect of neighboring cells become (see next section for more details about how neighboring effects were approached in the models). When larger cells are used, local and neighborhood effects are weak. Square cells measuring two kilometers on each side were chosen because the local effects are more relevant than neighborhood effects, as expected for a transportation infrastructure impact. Note that this dimension is coherent with the general reference that mass transit infrastructure service area is roughly a one-kilometer-radius, despite the uncertainties generated by Modifiable Areal Unit Problem (MAUP) and the possibility of infrastructure being located near the cell border. 
We calculated the urbanization rate in each period for each of the resulting 489 cells using the series of digital maps showing the extension of the metropolis' urban area in selected years since 1881. Variation in this variable is a proxy for urban expansion. Map 3 depicts the grid adopted and the evolution of São Paulo's urban footprint with current city borders. ${ }^{5}$ The shape and size of the city were captured using digital cartography of old maps and remote sensing analysis developed by the Metropolitan Planning Company of São Paulo (EMPLASA, 2002). Polygons of São Paulo’s urban footprint in 1881, 1897, 1914, 1929, 1947, 1962, 1980, 1997 and 2013 were used $^{6}$ in our empirical analysis, limiting our panel data to nine observations, with 15-year to 18-year periods between them. Measuring the urban footprint of the city from this data accounts for informal settlements, a phenomenon of great relevance when studying the urban development of São Paulo.

We also measured the number of buildings in the aforementioned years for each cell. The number of buildings is a proxy for building density in the cell. ${ }^{7}$ The data come from São Paulo's property tax records and, for each unit, include the square footage, type and year of construction, use, among other information. The database is updated annually by the São Paulo City Secretary of Finance for tax collection purposes, and is similar to the New York City Primary Land Use Tax Output (PLUTO) used by King (2011). Unit information was aggregated at the parcel level. To proxy for a measurement of the vertical development of the city, we use the construction date of each apartment or office building with more than three floors. ${ }^{8}$

One challenge of using this database for approximating density is we cannot be certain that the original structures are still in place, since buildings may have been constructed where another building stood previously, information not contained in the database. This potential bias is reduced by only including buildings with more than three floors. Demolition of buildings with more than three floors is rare; ${ }^{9}$ tall buildings built where another tall building previously stood represent a tiny component of the total number of buildings.

Map 4 and Graph 2 indicate that, as expected, buildings are higher and more frequent close to the city core. However, the presence of buildings with more than three-stories in almost the entire urban area of the city is also notable and consistent with Somekh's (2014) characterization of São Paulo as a highly vertical city. Another notable aspect is the existence of horizontal expanses that are not on the urban fringes. These areas overlap with construction restrictions due to land-use regulations and constraints, such as low-density zoning, landmarked historical districts, airports, parks, cemeteries, and university campuses. We control for these restrictions with control variables for the respective grid cells. Note, also, that many cells have missing values, meaning that these cells had no buildings in the past. In reality, we do not know if this means that there were no buildings with more than 3 floors in the area or if the information for this area is incomplete. Given the location of those cells we assumed that cells with missing information had no buildings with more than 3 floors. ${ }^{10}$ We check if our results are robust to eliminating those observations in the following section.

\footnotetext{
5 São Paulo had just one jurisdictional boundary change during the period of analysis, with the annexation of Santo Amaro municipality in 1935. This consolidation does not affect our data and results.

${ }^{6}$ The urban footprint for 2013 were produced by the authors using EMPLASA's polygons to define the training areas for supervised classification remote sensing of LANDSAT 7 images processed on ENVI 5.4.

7 Since the areas are the same for each cell, there was no need to normalize the variable by area.

8 In 2017, there were 2,917,255 properties in São Paulo classified as residential or commercial units, and 49\% of them were in one of the 57,832 vertical buildings in the city. Of these buildings, 94\% had more than three floors. The median age of the buildings in São Paulo was 40 years. In New York, the median age of all buildings was 70 years in 2011 (King, 2011, p. 25).

9 According to demolition authorizations granted by the Municipal Secretary of Urbanism and Licensing, less than $0.01 \%$ of three-story buildings that existed in 2000 were demolished during the following decade.

${ }^{10}$ Even though informal settlements are not included in property tax records, multi-family buildings with more than 3 floors in these areas are rare. The urbanization rate measurement accounts for informal settlements that are typically horizontal areas.
} 

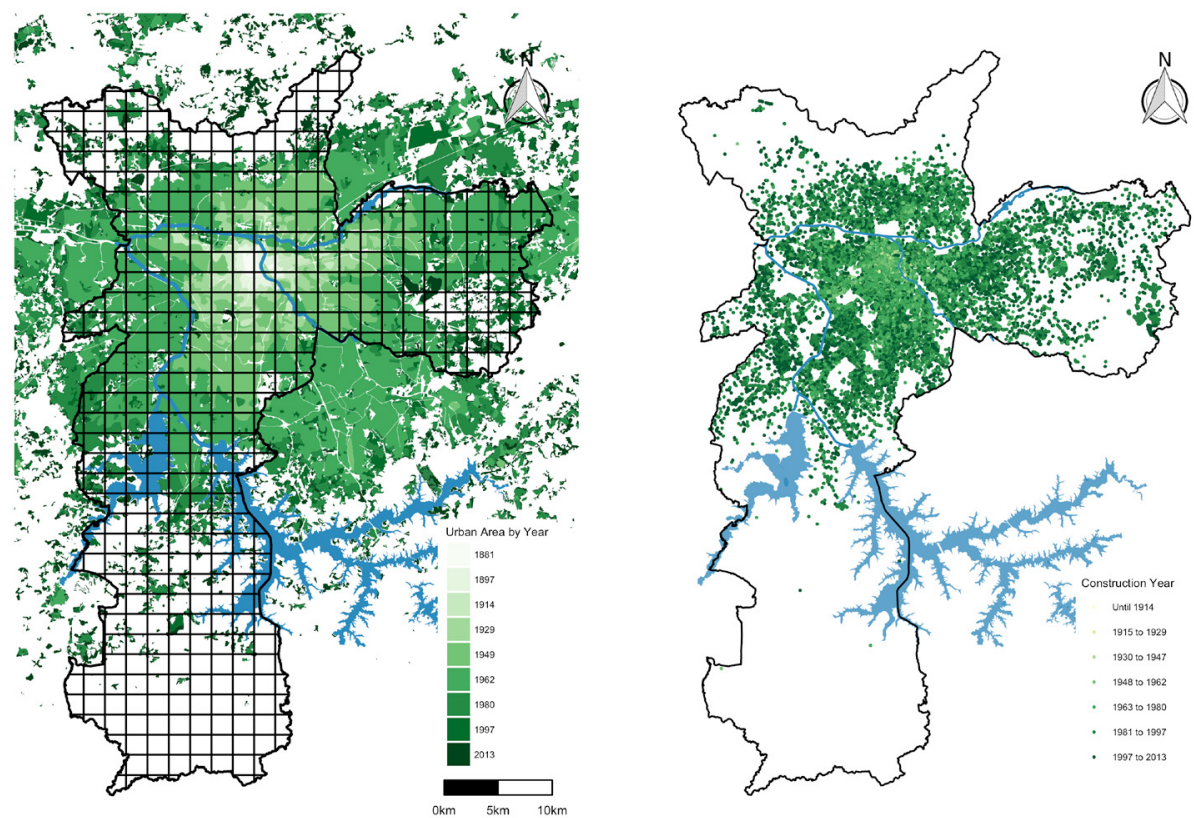

Map 3. Square grid of analysis and the evolution in São Paulo's urban area, 1881-2013

Source: The authors, using data from EMPLASA (2002) and classified Landsat 7 images

Map 4. Distribution of three-stories buildings in São Paulo and its construction year, 1881-2013

Source: The authors, using data from São Paulo’s land-use tax database

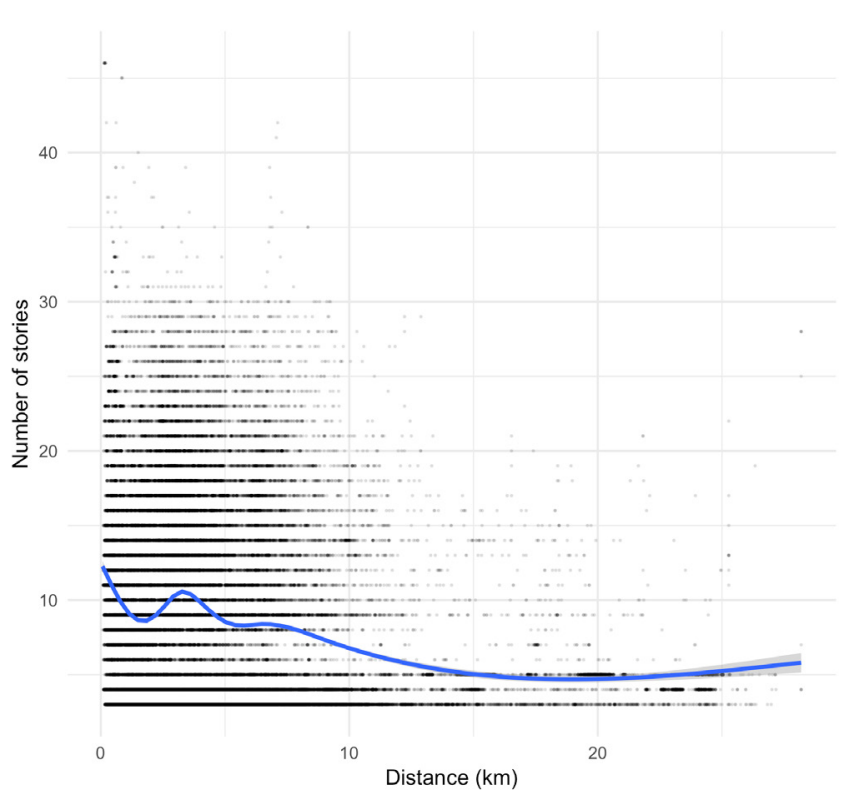

Graph 2. Building height, as a function of distance from the city center in São Paulo, 2013

Source: The authors, using data from São Paulo’s land-use tax database 
On the transportation side, we compiled into a single dataset GIS and historical data of old and current transit infrastructure (the location and when it began or ceased operations). Data on the subway, commuter rail, bus corridor, and highway systems were obtained directly from the public authorities responsible for operating each system and from the city of São Paulo's geospatial data website. Former streetcar lines were mapped using the detailed route descriptions available in Stiel (1978) and suburban rail data come from Giesbrecht $(2001,2018)$. The extent (in kilometers) of mass transit lines operating in each cell in each year is the measure of public transportation development used in our analysis.

We also include the extent of the arterial road network in each cell for each period. Sáo Paulo's city government maintains a database containing information about each street, avenue, and park in the city, including current and former official names, and when these were officially defined. Maintaining this information accurately and reliably is especially important for purposes of real estate registration and tax collection. We considered the date that a street, avenue or highway became official in the city as its inauguration, so we were able to trace the development of the main roadway system of São Paulo. Only streets, avenues and highways considered as structural in the city's Master Plan were included. In a number of cases, determining the date that certain main avenues were established is impossible, since they were not "inaugurated," but rather formalized over the years. We assume that these informal and likely precarious routes were not part of the urban network and were not regularly used for heavy traffic. The formalization of such roads in the city is often the way an urban road becomes established and paved, permitting, for example, the circulation of urban buses. Other streets and avenues have a clear inauguration date.

Admittedly, network length is not the best measure of transportation capacity or accessibility. Many other attributes better characterize public transit networks, such as frequency of service, time and cost of travel, and measures of accessibility to jobs and public services. Ideally, we would have included historical spatial data on formal and informal bus routes that operated in the city. However, consistent and comprehensive historical data for these measurements were unavailable. The network length variables provide a consistent historical data series, which was not possible for other transportation indicators.

\subsection{Empirical strategy}

We test our hypotheses using Granger causality, following Levinson (2008a) and King (2011) (see, also, Cervero \& Hansen; 2002; Fulton, Noland, Meszler, \& Thomas, 2000). Granger's test verifies whether certain phenomena are leading indicators of a specific phenomenon of interest, measuring the ability to predict future values of a dependent variable using prior values of independent variables. Granger models were developed to determine the direction of causality among related variables (Granger, 1969), but do not offer "true causality" verification. Granger estimated coefficients indicate how strong a relationship between variables is over time and whether changes in an independent variable are a leading indicator of future changes in a dependent variable (Angrist $\&$ Pischke, 2008, p. 177). ${ }^{11}$ The results of these models should not be interpreted as proof of strict causation, but rather as predictive causality (or Granger causality) - an estimate of the strength of the relationship between the presence of one phenomenon and the subsequent measurement of another. In this case, we measured whether transportation improvements during one period predict urban development in the subsequent period in each grid cell. We then did the inverse, with lagged urban development measures predicting transportation investments in the subsequent period.

More specifically, we use the same model for different dependent variables of interest: urbanization rate $\left(U_{i, t}\right)$ in Model 1, number of buildings $\left(N_{i, t}\right)$ in Model 2, mass transit network length $\left(T n t_{i, t}\right)$ in Model 3, and road network length $\left(R n t_{i, t}\right)$ in Model 4. Following Levinson (2008a), the general model 
(using Model 1 as an example) is:

$U_{i, t}=\beta_{1} U_{i, t-1}+\beta_{2} \Delta T n_{i, t-1}+\beta_{3} \Delta R n t_{i, t-1}+\beta_{4} W \Delta T n t_{i, t-1}+\beta_{5} W \Delta R n t_{i, t-1}+\beta_{6} \Delta N_{i, t-1}+\beta_{7} W \Delta N_{t-1}+\beta_{8} W \Delta U_{t-1}$ $+\beta_{9} Z_{i}^{\prime}+\beta_{10} \Delta C_{t-1}+u_{i t}$

We expect the percentage of urbanized area of a cell in a period $\left(U_{i, t}\right)$ to be explained by the urbanization rate observed in the same cell in the previous decade $\left(U_{i, t-1}\right)$, which is commonly known as temporal autocorrelation when working with time-series cross-sections. Transportation improvements occurring during the previous period are expected to affect subsequent urban development measures, so the model includes lagged road network length change $\left(\Delta R n t_{i, t-1}\right)$ and mass transit network length change $\left(\Delta T n t_{i, t-1}\right) .{ }^{12}$ What happens in neighboring cells might also have some impact (i.e., spatial autocorrelation), so neighbor cells' changes in the transportation network (i.e., $W \Delta T n t_{i, t-1}$ ) and $W \Delta R n t_{i, t-1}$ ) and urbanization (i.e., $W \Delta N_{i, t-1}$ ) and $W \Delta U_{i, t-1}$ ) were included in the model using a matrix of spatial interaction weights $(W)$. Given the concentric and radial characteristics of the city, we built a directional (or anisotropic) queen contiguity weight matrix (illustrated in Figure 1): for each cell (in red) we consider as neighbors (in blue) just the cells that are closer to the city center (Sé Square in the case of São Paulo, indicated by *). As there is no negative variation between periods in the urban and transportation development variables previously described, negative coefficients are unexpected and one-tailed p-values were used to test the significance of the coefficients for these variables in the regressions reported in the next section.

We controlled for a vector of cell-specific variables that do not change with time $\left(Z_{i}^{\prime}\right)$ and can influence urbanization, capturing area fixed effects: distance from the $\mathrm{CBD}$, terrain roughness ${ }^{13}$ and restrictions on building heights. ${ }^{14}$ Additionally, if São Paulo expands, areas within the city are also more likely to expand, so changes in the percentage of urban area throughout the city during the previous period $\left(\Delta C_{t-1}\right)$ were also considered in the model as a time-specific variable that does not change within cells.

One might argue that the model should control for socio-economic variables. Brazil's first census is from 1872, but since then the city has been geographically divided in many different ways for census and survey purposes. There is no consistent spatial unit for historical socio-economic data disaggregated within the city. Also due to data availability constraints, we had to limit our analysis to Sáo Paulo, as road development data were not available for other cities in the metropolitan region.

Finally, working with time series cross-sectional data introduces potential temporal autocorrelation. Several panel data techniques have been developed to address this potential bias when working with this kind of data. Ordinary least squares (OLS) with panel-corrected standard errors (PCSE) and using a lagged dependent variable, as proposed by Beck \& Katz (1995), is one of the most often used. The Arellano-Bond estimator is also often used in dynamic panel models, but it does not allow the inclusion of time-constant variables, such as distance from the CBD - an important control variable in our models. So, we use PCSE and a balanced panel dataset.

11 The following 15-year to 18-year periods were considered: 1881-1897,1897-1914, 1914-1929, 1929-1947, 19471962, 1962-1980, 1980-1997, and 1997-2013. Models using two-period lags were tested, but the results were not significant.

12 Including the extent of road network and transit network in the same model might generate autocorrelation effects. However, in our dataset, the observed correlation between these variables is 0.3 , indicating only modest concern.

${ }^{13}$ The rationale behind the inclusion of this variable is that a high measure of roughness (unevenness) makes terrain more difficult for building; in this case, roughness was measured as the standard deviation of land elevations (heights) in a cell using a natural terrain elevation model of 90 -meter resolution.

${ }_{14}$ The percentage of the cell's area covered by low-density zoning, landmarked historical districts, airport, parks, cemeteries, university campuses, and other special land uses. 


\subsection{Results}

Table 1 presents the results for the four models using the whole sample. The Granger effects of transportation factors in urban expansion are significant only for improvements in the local road network (Model 1). This means that over São Paulo's history, urban expansion followed road improvements. At the same time, Model 3 indicates that urban expansion was also followed by road investments. So, roads and urban expansion have pushed and pulled each other in parallel over São Paulo’s history, supporting the "orderliness hypothesis" in this case. In contrast, and consistent with the historical overview of São Paulo's urban and transportation development, mass transit investment in the previous period is not a significant predictor of urban expansion (Model 1). Urban expansion is also not a significant predictor for mass transit extension (Model 4). That is, mass transit does not push expansion and expansion does not pull mass transit.

Turning to density, we find no significant effect of road network growth on building densification (Model 2) and vice versa (Model 3); road network growth and building density do not feed each other. In contrast, we find evidence that mass transit infrastructure investment led to building densification (Model 2); but, increases in the number of buildings were not followed by additional mass transit investment (Model 4). In other words, the "orderliness hypothesis" identified for road investment and urban expansion is not observed for mass transit and new buildings; instead, we find evidence of the "leading transportation" phenomenon. 
Table 1. Results for 1881-2013

\begin{tabular}{|c|c|c|c|c|c|c|c|c|}
\hline \multirow[b]{2}{*}{ Variables } & \multicolumn{2}{|c|}{$\begin{array}{c}\text { Predicting Urban Rate } \\
\text { (Model 1) }\end{array}$} & \multicolumn{2}{|c|}{$\begin{array}{c}\text { Predicting No Buildings } \\
\text { (Model 2) }\end{array}$} & \multicolumn{2}{|c|}{$\begin{array}{l}\text { Predicting Road } \\
\text { Network Length } \\
\quad \text { (Model 3) }\end{array}$} & \multicolumn{2}{|c|}{$\begin{array}{l}\text { Predicting Transit } \\
\text { Network Length } \\
\text { (Model 4) }\end{array}$} \\
\hline & Mean & P-value & Mean & P-value & Mean & P-value & Mean & P-value \\
\hline Constant & $\begin{array}{c}0.1200 \\
(0.0105)\end{array}$ & $\begin{array}{l}0.0000 \\
* * *\end{array}$ & $\begin{array}{l}25.7178 \\
(4.8893)\end{array}$ & $\begin{array}{c}0.0000 \\
* * *\end{array}$ & $\begin{array}{c}0.6054 \\
(0.0617)\end{array}$ & $\begin{array}{c}0.0000 \\
* * *\end{array}$ & $\begin{array}{l}1.0618 \\
(0.1951)\end{array}$ & $\begin{array}{c}0.0000 \\
* * *\end{array}$ \\
\hline $\begin{array}{l}\text { Lagged Predicted } \\
\text { Variable }(\mathrm{t}-1)\end{array}$ & $\begin{array}{c}0.8341 \\
(0.0112)\end{array}$ & $\begin{array}{c}0.0000 \\
* * *\end{array}$ & $\begin{array}{l}1.061 \\
(0.009)\end{array}$ & $\begin{array}{c}0.0000 \\
* * *\end{array}$ & $\begin{array}{c}0.9554 \\
(0.0092)\end{array}$ & $\begin{array}{c}0.0000 \\
* * *\end{array}$ & $\begin{array}{c}1.1084 \\
(0.0079)\end{array}$ & $\begin{array}{c}0.0000 \\
* * *\end{array}$ \\
\hline $\begin{array}{l}\Delta \text { Urban Rate } \\
(\mathrm{t}-1-\mathrm{t}-2)\end{array}$ & - & - & $\begin{array}{c}6.0476 \\
(12.974)\end{array}$ & 0.3192 & $\begin{array}{l}1.8515 \\
(0.1531)\end{array}$ & $\begin{array}{c}0.0000 \\
* * *\end{array}$ & $\begin{array}{c}0.2506 \\
(0.4873)\end{array}$ & 0.3050 \\
\hline $\begin{array}{l}\Delta \text { Neighbor Urban } \\
\text { Rate } \\
(\mathrm{t}-1-\mathrm{t}-2)\end{array}$ & $\begin{array}{c}0.2327 \\
(0.0202)\end{array}$ & $\begin{array}{c}0.0000 \\
* * *\end{array}$ & $\begin{array}{l}-63.9962 \\
(14.665)\end{array}$ & 0.9999 & $\begin{array}{c}0.5058 \\
(0.1757)\end{array}$ & $\begin{array}{c}0.0020 \\
* * *\end{array}$ & $\begin{array}{l}0.15514 \\
(0.5544)\end{array}$ & 0.7826 \\
\hline $\begin{array}{l}\Delta \text { No Buildings } \\
(\mathrm{t}-1-\mathrm{t}-2)\end{array}$ & $\begin{array}{c}0.0000 \\
(0.0000)\end{array}$ & 0.2177 & - & - & $\begin{array}{c}0.0000 \\
(0.0003)\end{array}$ & 0.5359 & $\begin{array}{l}-0.0052 \\
(0.0011)\end{array}$ & 0.9999 \\
\hline $\begin{array}{l}\Delta \text { Neighbor No } \\
\text { Buildings }(t-1-t-2)\end{array}$ & $\begin{array}{c}0.0000 \\
(0.0000)\end{array}$ & 0.8508 & $\begin{array}{c}0.2275 \\
(0.0142)\end{array}$ & $\begin{array}{c}0.0000 \\
* * *\end{array}$ & $\begin{array}{l}-0.0001 \\
(0.0002)\end{array}$ & 0.6844 & $\begin{array}{l}-0.0002 \\
(0.0006)\end{array}$ & 0.6406 \\
\hline $\begin{array}{l}\Delta \text { Road Network } \\
\text { Length } \\
(\mathrm{t}-1-\mathrm{t}-2)\end{array}$ & $\begin{array}{c}0.0111 \\
(0.0033)\end{array}$ & $\begin{array}{c}0.0004 \\
* * *\end{array}$ & $\begin{array}{c}0.9592 \\
(1.6991)\end{array}$ & 0.2878 & - & - & $\begin{array}{c}0.0889 \\
(0.0836)\end{array}$ & 0.1808 \\
\hline $\begin{array}{l}\Delta \text { Neighbor Road Net- } \\
\text { work Length }(t-1-t-2)\end{array}$ & $\begin{array}{c}0.0189 \\
(0.0041) \\
\end{array}$ & $\begin{array}{c}0.0000 \\
* * * \\
\end{array}$ & $\begin{array}{l}-5.6229 \\
(2.1588) \\
\end{array}$ & 0.9953 & $\begin{array}{l}0.0956 \\
(0.022) \\
\end{array}$ & $\begin{array}{c}0.0000 \\
* * * \\
\end{array}$ & $\begin{array}{l}-0.0677 \\
(0.0782) \\
\end{array}$ & 0.8078 \\
\hline $\begin{array}{l}\Delta \text { Mass Transit Net- } \\
\text { work Length }(\mathrm{t}-1-\mathrm{t}-2)\end{array}$ & $\begin{array}{l}-0.0014 \\
(0.0012)\end{array}$ & 0.8809 & $\begin{array}{l}9.2983 \\
(0.6111)\end{array}$ & $\begin{array}{c}0.0000 \\
* * *\end{array}$ & $\begin{array}{c}0.0067 \\
(0.0073)\end{array}$ & 0.1762 & - & - \\
\hline $\begin{array}{l}\Delta \text { Neighbor Mass Tran- } \\
\text { sit Network Length } \\
(\mathrm{t}-1-\mathrm{t}-2)\end{array}$ & $\begin{array}{c}0.0005 \\
(0.0008)\end{array}$ & 0.2710 & $\begin{array}{l}-0.3902 \\
(0.4193)\end{array}$ & 0.8238 & $\begin{array}{l}0.0048 \\
(0.005)\end{array}$ & 0.1686 & $\begin{array}{c}0.0268 \\
(0.0136)\end{array}$ & $\begin{array}{c}0.0245 \\
* *\end{array}$ \\
\hline $\begin{array}{l}\Delta \text { Predicted Variable in } \\
\text { the whole City }(\mathrm{t}-\mathrm{t}-1)\end{array}$ & $\begin{array}{c}0.8888 \\
(0.0476)\end{array}$ & $\begin{array}{c}0.0000 \\
* * *\end{array}$ & $\begin{array}{c}0.0024 \\
(0.0002)\end{array}$ & $\begin{array}{c}0.0000 \\
* * *\end{array}$ & $\begin{array}{c}0.0016 \\
(0.0001)\end{array}$ & $\begin{array}{c}0.0000 \\
* * *\end{array}$ & $\begin{array}{c}0.0019 \\
(0.0003)\end{array}$ & $\begin{array}{c}0.0000 \\
* * *\end{array}$ \\
\hline Distance to CBD & $\begin{array}{l}-0.0045 \\
(0.0004)\end{array}$ & $\begin{array}{c}0.0000 \\
* * *\end{array}$ & $\begin{array}{l}-1.3875 \\
(0.1916)\end{array}$ & $\begin{array}{c}0.0000 \\
* * *\end{array}$ & $\begin{array}{l}-0.0272 \\
(0.0023)\end{array}$ & $\begin{array}{c}0.0000 \\
* * *\end{array}$ & $\begin{array}{l}-0.0435 \\
(0.007)\end{array}$ & $\underset{* * *}{0.0000}$ \\
\hline Terrain roughness & $\begin{array}{l}-0.0011 \\
(0.0002)\end{array}$ & $\begin{array}{c}0.0000 \\
* * *\end{array}$ & $\begin{array}{l}-0.1437 \\
(0.1092)\end{array}$ & 0.1882 & $\begin{array}{l}-0.0053 \\
(0.0013)\end{array}$ & $\begin{array}{c}0.0000 \\
* * * \\
\end{array}$ & $\begin{array}{l}-0.0057 \\
(0.0041)\end{array}$ & 0.1649 \\
\hline Land-use restrictions & $\begin{array}{l}-0.0575 \\
(0.0183)\end{array}$ & $\begin{array}{c}0.0017 \\
* * *\end{array}$ & $\begin{array}{r}-13.6389 \\
(9.3982)\end{array}$ & 0.1468 & $\begin{array}{c}0.2190 \\
(0.1113)\end{array}$ & $\begin{array}{c}0.0490 \\
* *\end{array}$ & $\begin{array}{l}-0.4255 \\
(0.3538)\end{array}$ & 0.2292 \\
\hline No Observations & \multicolumn{2}{|c|}{2723} & \multicolumn{2}{|c|}{2723} & \multicolumn{2}{|c|}{2723} & \multicolumn{2}{|c|}{2723} \\
\hline $\mathrm{R}^{2}$ & \multicolumn{2}{|c|}{0.8531} & \multicolumn{2}{|c|}{0.9115} & \multicolumn{2}{|c|}{0.9081} & \multicolumn{2}{|c|}{0.9391} \\
\hline
\end{tabular}

Notes: Significance threshold: ${ }^{*} 0.1,{ }^{* *} 0.05,{ }^{* * *} 0.01$. Standard deviation calculated as panel-corrected SE. t-1 indicates 13 -year to 18 -year lag. Balanced panel dataset with 389 grid cells $(2 \mathrm{~km})$. Cells with urbanization rate and number of buildings equal to zero in the end-period were included in the regression. 
The control variables have the expected coefficient estimates. Model 4 reveals the inertial tendency of mass transit in São Paulo, which is only explained by its lagged value, the variation in the entire city, the cell's distance to CBD and the presence of land-use restrictions. Interestingly, since building density does not follow urban expansion (Model 2), our results suggest that the city is sprawling outward, but not, subsequently, upward; as expected, since São Paulo's sprawl was pushed by low-income self-built housing. When predicting the percentage of urban area in each cell per period (Model 1), the cell's lagged urban rate value is highly significant and approaches one, as expected from a Granger causality model, and because the urban footprint in each cell should remain the same between periods in the absence of outside factors. Indeed, the lagged value of the predicted variable is significant with a parameter close to one in all the models, also a reason for the high R2 values (ranging between 0.83 and 0.93 ). In this case, a large R2 might also be signaling endogeneity.

Non-lagged changes in city size are also significant and positive. All the stationary variables are negatively significant in Model 1, revealing that urbanization declines with distance from the city core, terrain roughness, and the presence of land-use regulations restricting tall buildings as expected.

Table 2 presents estimated elasticities of relevant significant urban- and transportation-development coefficients from all models. ${ }^{15}$ Interestingly, the estimates suggest that mass transit had a stronger effect on building densification in relevant cells than road network expansion did on urbanization, but this effect is local and does not spread to neighboring cells.

Table 2. Elasticities from models 1 to 4 1881-2013

\begin{tabular}{|c|c|c|c|c|c|}
\hline \multicolumn{3}{|c|}{$\begin{array}{c}\text { Elasticities - Predicting Urban Rate } \\
\text { Model } 1 \\
\end{array}$} & \multicolumn{3}{|c|}{$\begin{array}{c}\text { Elasticities - Predicting Road Network Length } \\
\text { Model } 3 \\
\end{array}$} \\
\hline$\Delta$ Road Network Length & 0.0007 & $* * *$ & $\Delta$ Urban Rate & 0.0028 & $* * *$ \\
\hline$\Delta$ Neigh. Road Network Length & 0.0012 & $* * *$ & $\Delta$ Neighbor Urban Rate & 0.0007 & $* * *$ \\
\hline$\Delta$ Mass Transit Network Length & - & & $\Delta N^{\circ}$ Buildings & - & \\
\hline$\Delta$ Neigh. Mass Transit Network Length & - & & $\Delta$ Neighbor No Buildings & - & \\
\hline \multicolumn{3}{|c|}{$\begin{array}{c}\text { Elasticities - Predicting No Buildings } \\
\text { Model } 2\end{array}$} & \multicolumn{3}{|c|}{$\begin{array}{c}\text { Elasticities - Predicting Mass Transit } \\
\text { Network Length } \\
\text { Model } 4\end{array}$} \\
\hline$\Delta$ Road Network Length & - & & $\Delta$ Urban Rate & - & \\
\hline$\Delta$ Neigh. Road Network Length & - & & $\Delta$ Neighbor Urban Rate & - & \\
\hline$\Delta$ Mass Transit Network Length & 0.0040 & $* * *$ & $\Delta \mathrm{N}^{\circ}$ Buildings & - & \\
\hline$\Delta$ Neigh. Mass Transit Network Length & - & - & $\Delta$ Neighbor $N^{o}$ Buildings & - & \\
\hline
\end{tabular}

Notes: Significance threshold: ${ }^{*} 0.1,{ }^{* *} 0.05,{ }^{* * *} 0.01$. Balanced panel dataset with 389 grid cells $(2 \mathrm{~km})$. Cells with urbanization rate and number of buildings equal to zero in the end-period were included in the regression.

15 Elasticities were calculated following Levinson (2008a) using mean values of our independent (changes in urban and transportation measurements) and dependent variables, and the significant Granger coefficients of impact estimated in the regression analyzes. More specifically, the elasticities were calculated as:

Elasticity $=0.01^{*}$ mean $\left(\right.$ IndepVar) ${ }^{*}$ GrangerCoef.

$$
\text { mean(DepVar) }
$$


The results presented in Tables 1 and 2 cover nearly 150 years, from 1881 to 2013. However, São Paulo's transport and urbanization history can arguably be distinguished by periods marked by a few critical junctures: the first decades of significant urban growth in the city of São Paulo, between 1881 and 1929, before the decision to prioritize road development; and the period after "modern" investment in mass transit, starting in 1974. We apply the same analytical approach as above, for these three distinct periods. Table 3 presents the estimated elasticities for the period between 1881 and $1929,{ }^{16}$ which suggest different development forces at work until the third decade of the twentieth century. In this early period, we already observe the orderliness of development for roads and urban expansion as exhibited in the longer-period analysis. However, during the first years of the 20th century in São Paulo, public transit development also conformed to the "orderliness hypothesis," leading and following urban expansion (Models 1.1 and 4.1, respectively) and consistent with a "streetcar suburb" (Warner, 1978) model of development. Relative to the "orderliness" roadway effect on urbanization observed for the entire period, the mass transit network effect was more modest during this shorter period. The results suggest that public transit followed city growth during this multi-modal-induced urbanization era, reaching areas close to what was then the boundary of the dense urban area of São Paulo.

Table 3. Elasticities from Models 1.1 to 4.1, São Paulo, 1881-1929

\begin{tabular}{|c|c|c|c|c|c|}
\hline \multicolumn{3}{|c|}{$\begin{array}{c}\text { Elasticities - Predicting Urban Rate } \\
\text { Model 1.1 } \\
\end{array}$} & \multicolumn{3}{|c|}{$\begin{array}{c}\text { Elasticities - Predicting Road Network Length } \\
\text { Model } 2.1\end{array}$} \\
\hline$\Delta$ Road Network Length & 0.0003 & $* *$ & $\Delta$ Urban Rate & 0.0009 & $* * *$ \\
\hline$\Delta$ Neigh. Road Network Length & - & & $\Delta$ Neighbor Urban Rate & - & \\
\hline$\Delta$ Mass Transit Network Length & 0.0001 & ** & $\Delta \mathrm{N}^{\circ}$ Buildings & - & \\
\hline$\Delta$ Neigh. Mass Transit Network Length & - & & $\Delta$ Neighbor No Buildings & - & \\
\hline \multicolumn{3}{|c|}{$\begin{array}{c}\text { Elasticities - Predicting No Buildings } \\
\text { Model 3.1 }\end{array}$} & \multicolumn{3}{|c|}{$\begin{array}{c}\text { Elasticities - Predicting Mass Transit Network Length } \\
\text { Model 4.1 }\end{array}$} \\
\hline$\Delta$ Road Network Length & - & & $\Delta$ Urban Rate & 0.0019 & $* *$ \\
\hline$\Delta$ Neigh. Road Network Length & - & & $\Delta$ Neighbor Urban Rate & - & \\
\hline$\Delta$ Mass Transit Network Length & 0.0038 & $* * *$ & $\Delta \mathrm{N}^{\circ}$ Buildings & - & \\
\hline$\Delta$ Neigh. Mass Transit Network Length & 0.0128 & $* * *$ & $\Delta$ Neighbor No Buildings & - & \\
\hline
\end{tabular}

Notes: Significance threshold: ${ }^{*} 0.1,{ }^{* *} 0.05,{ }^{* * *} 0.01$. Balanced panel dataset with 535 grid cells $(0.75 \mathrm{~km})$. Cells with urbanization rate and number of buildings equal to zero in the end-period were included in the regression.

Interestingly, we find a Granger effect of mass transit on building density in this early period when the number of vertical buildings was low, only around two hundred buildings with more than three floors in 1929. These results show how streetcars, the prevalent transportation mode in this period, played a central role in the urban structure of São Paulo during this first era. The expansion of the Trolley system interacted with both the city's vertical development and urban expansion.

The decades between 1929-1974 mark the period of most intense population, urban and economic growth in the history of São Paulo and also encompass the period when most of the road infrastructure

${ }^{16}$ To allow shorter intervals and more observations, we included polygons of the urban footprint of the city mapped by Kako (2013) using the same method used by EMPLASA (2002). Observations for the following years compose the panel dataset: $1881,1890,1897,1905,1914,1922,1929$. The data sources for buildings, road development, and mass transit infrastructure are the same as used before. Considering that the city in 1929 was just $10 \%$ of its urban area in 2013, we conducted new tests to define the cell size adequate for this shorter period, and we end up using square cells measuring 750 meters on each side. The table of OLS results for the period 1881-1929 are available in the Appendices. 
- planned and not planned in the Avenues Plan - was implemented. São Paulo’s population increased by 7 times during this period (from one million to seven million inhabitants) while its urban area increased by more than 10 times. The results (Table 4) indicate that this period did not match the intrinsic landuse-transportation relationship observed in the previous period. ${ }^{17} \mathrm{Few}$ investments in public transport were made during these decades, and mass-transit oriented development fails to characterize São Paulo's urban development, with non-significant results in models 1.2, 2.2, and 4.2. The only significant land use-transportation relationship in this period supports the reactive transportation hypothesis (Model 3.2). In other words, throughout this period of immense growth in the city, road transportation was only able to keep up with São Paulo’s urban expansion but did not guide or direct it.

Table 4. Elasticities, from Models 1.2 to 4.2 for 1929-1974

\begin{tabular}{|lllc|}
\hline \multicolumn{1}{|c|}{$\begin{array}{c}\text { Elasticities } \text { - Predicting Urban Rate } \\
\text { Model 1.2 }\end{array}$} & \multicolumn{2}{c|}{ Elasticities - Predicting Road Network Length } \\
Model 3.2
\end{tabular}

Notes: Significance threshold: ${ }^{*} 0.1,{ }^{* *} 0.05,{ }^{* * *} 0.01$. Balanced panel dataset with 557 grid cells $(1.5 \mathrm{~km})$. Cells with urbanization rate and number of buildings equal to zero in the end-period were not included in the regression.

Finally, examining the most recent period, 1974 to $2013,{ }^{18}$ supports the "orderliness" hypothesis for roadways; São Paulo's road network investment and urban expansion push each other (Models 1.3 and 3.3). Notably, the strength of the push/pull of roadways and urban expansion are lower during this later period. Interestingly, although representing the time when the city's "modern" mass transit infrastructure was built, this period reveals no relationship between transit infrastructure and densification. This suggests that all transit-leaded "densification" in the city happened during the early era of São Paulo's urbanization. ${ }^{19}$

\footnotetext{
17 We considered square cells measuring 1,5 kilometers on each side and observations for the following years: 1929, 1935, 1942, 1949, 1954, 1962, 1968, 1974. The table of OLS results for the period 1929-1974 are available in the Appendices. 18 We considered square cells measuring 2 kilometers on each side and observations for the following years: 1974, 1980, 1985, 1992, 1997, 2002, 2007, 2013. The table of OLS results for the period 1974-2013 are available in the Appendices. ${ }^{19}$ Admittedly, the imperfect way we capture building density in this analysis could mask important densification that actually took place in the form of new towers replacing smaller towers.
} 
Table 5. Elasticities, from Models 1.3 to 4.3 for 1974-2013

\begin{tabular}{|c|c|c|c|c|c|}
\hline \multicolumn{3}{|c|}{$\begin{array}{c}\text { Elasticities - Predicting Urban Rate } \\
\text { Model 1.3 }\end{array}$} & \multicolumn{3}{|c|}{$\begin{array}{c}\text { Elasticities - Predicting Road Network Length } \\
\text { Model 3.3 }\end{array}$} \\
\hline$\Delta$ Road Network Length & 0.0001 & $* * *$ & $\Delta$ Urban Rate & 0.0009 & $* * *$ \\
\hline$\Delta$ Neigh. Road Network Length & 0.0003 & $* * *$ & $\Delta$ Neighbor Urban Rate & - & \\
\hline$\Delta$ Mass Transit Network Length & - & & $\Delta \mathrm{N}^{\circ}$ Buildings & - & \\
\hline$\Delta$ Neigh. Mass Transit Network Length & - & & $\Delta$ Neighbor No Buildings & - & \\
\hline \multicolumn{3}{|c|}{$\begin{array}{c}\text { Elasticities - Predicting No Buildings } \\
\text { Model } 2.3\end{array}$} & \multicolumn{3}{|c|}{$\begin{array}{l}\text { Elasticities - Predicting Mass Transit Network Length } \\
\text { Model 4.3 }\end{array}$} \\
\hline$\Delta$ Road Network Length & - & & $\Delta$ Urban Rate & - & \\
\hline$\Delta$ Neigh. Road Network Length & - & & $\Delta$ Neighbor Urban Rate & - & \\
\hline$\Delta$ Mass Transit Network Length & - & & $\Delta N^{\circ}$ Buildings & - & \\
\hline$\Delta$ Neigh. Mass Transit Network Length & - & & $\Delta$ Neighbor No Buildings & - & \\
\hline$\Delta$ Urban Rate & 0.0012 & ** & & & \\
\hline
\end{tabular}

Notes: Significance threshold: ${ }^{*} 0.1,{ }^{* *} 0.05,{ }^{* * *} 0.01$. Balanced panel dataset with 372 grid cells $(2 \mathrm{~km})$. Cells with urbanization rate and number of buildings equal to zero in the end-period were included in the regression.

Comparing the entire period to the earlier and later sub-periods of São Paulo's development shows distinct patterns. In the pre-car period (1881 to 1929), public transit and urbanization developed in concert while road investments reacted to urban expansion (itself being driven in part by transit investments). When, after nearly half a century of no investments, mass transit investment does resume, road transport and expansion continue to move together, while public transit has no observable role in urban expansion or densification. In fact, density along transit corridors is currently relatively low in São Paulo as recognized by the 2014 Master Plan that called for lower densities outside transit corridors and higher densities in areas within $800 \mathrm{~m}$ of them. Table 6 summarizes the land-use and transportation connection found for each period considered.

Table 6. Transportation and urban development connections for different periods

\begin{tabular}{|c|c|c|c|c|c|c|c|c|c|c|c|}
\hline & \multicolumn{2}{|c|}{ A: Whole Period } & & \multicolumn{2}{|c|}{ B: $1881-1929$} & \multicolumn{3}{|c|}{ C: $1929-1974$} & \multicolumn{3}{|c|}{ D: $1974-2013$} \\
\hline & Expansion & Density & & Expansion & Density & & Expansion & Density & & Expansion & Density \\
\hline $\begin{array}{l}\mathscr{0} \\
\mathscr{0} \\
\mathscr{2}\end{array}$ & Ordered & - & 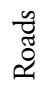 & Ordered & - & 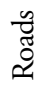 & $\begin{array}{l}\text { Reactive } \\
\text { Transport }\end{array}$ & - & 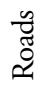 & Ordered & - \\
\hline . & - & $\begin{array}{l}\text { Leading } \\
\text { Transport }\end{array}$ & 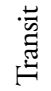 & Ordered & $\begin{array}{l}\text { Leading } \\
\text { Transport }\end{array}$ & 莺 & - & - & 苞 & - & - \\
\hline
\end{tabular}

At least two limitations to our analysis cast some doubt on the results. First, for cells with missing information about the number of buildings with more than 3 floors, this variable was set to zero. ${ }^{20}$ This poses two problems. First, the actual value for this variable might not be zero, although we believe that this is very unlikely given the location of those cases. Second, the large proportion of "zeros" in an

${ }^{20}$ We would like to thank an anonymous referee for calling our attention to this matter. 
independent variable might distort the results. To assess possible impacts on our results, we ran all the regressions, considering just cells with no missing information. The results (Tables 10 to 17 in Appendix B) show no changes relative to the results presented in Tables 1 to 6 . Another limitation is that the coefficients on the lagged variable are close to 1 , making us suspect that the series might be non-stationary. We ran the system in differences to correct for this potential problem and get the same results (Table 18 in Appendix B). So, we believe that our results are somewhat robust to different samples and specifications.

\section{$5 \quad$ Discussion and conclusions}

Interestingly, for the whole period analyzed, orderliness was only found for the relationship between road transport and urban expansion. This means that once a new settlement is established roads will follow and, once roads are built, urbanization will follow. Living in a settlement requires some accessibility. New settlements apparently pressure the government to pave the precarious roads necessary for initial settlement and these new roads further open the opportunity for new settlements. This suggests "orderliness," but does not imply real planning. The lack of connection between road transport and building densification suggests a perpetual process: a more distant place is occupied instead of consolidating the existing.

This result is aligned with a hypothesis commonly stated in the literature that road transportation played an important role in the expansion of São Paulo's low-income peripheries. But, it also shows urban expansion drove road network infrastructure growth. Although we lacked historical spatial data on formal and informal bus routes, part of the effect is likely due to the expansion of bus services (formal and informal), since poor workers living on the periphery rarely relied on cars for daily travel until the end of the 1970s (see Graph 1).

For the entire period, both road and mass transit investments were followed by some kind of urban development: urban expansion in the case of new roads and vertical buildings in the case of mass transit. The latter suggests the "leading transportation hypothesis," with mass transit stimulating densification, a commonly recommended practice in modern land use and transportation planning (i.e., transit-oriented development).

However, more detailed analysis finds that the relationship between mass transit and densification only holds for São Paulo's early streetcar era. In the early twentieth century, the golden era of streetcars, public transit led and followed the expansion of the city's urban footprint. This evidence is aligned with a "streetcar suburb" model of development elsewhere in the world at this time (e.g., London, Boston) (Levinson, 2008b; Warner, 1978): streetcars and railways were stimulating land development and value appreciation in the early twentieth century, generating cross-profits from real estate. The Light Company's ties to real estate activities, as briefly mentioned, can help in understanding this phenomenon of "coordinated" growth in São Paulo in this period. Since those two activities (mass transit and housing development) present cross externalities, coordinating them leads to a more efficient model of urban growth.

Uncontrolled urban growth intensified during the following period when real estate development had no ties to public transit operators. In the late 1920s, São Paulo's transportation and urban development were at a critical juncture, with two transportation plans under debate, which would define the type of transport technology that would subsequently predominate in the city. Our analysis suggests that the choice to implement the Avenue Plan had important consequences for the form of urban growth. São Paulo was growing extremely fast, population density was viewed as a public problem, the automobile was already being viewed as the ultimate technology of modernity, and the streetcar system was fraught with operational problems. The choice for road development in the late 1920s undoubtedly shaped São Paulo. It helped create a road-oriented city that is highly dependent on its system of $14,000+$ 
buses, and today struggles with congestion, high emission levels, and lengthy commutes. The same choice has been made in cities around the world.

In the analysis of critical junctures, the institutional path taken matters along with the paths that were not taken (Capoccia, 2016). It is, of course, impossible to verify what would have happened if the city had opted to develop a mass transit system rather than implementing the Avenue Plan in the late 1920s. Would São Paulo be a transit-oriented city today had it taken this other option? Would it be less spatially segregated? Would it be as big?

While we cannot answer those questions, our analysis shows that during the 40 years when road development dominated its transportation agenda, the city expanded massively. And, subsequent investments in high-capacity transit would barely make up lost ground. The "modern" subway system was built in consolidated, already dense neighborhoods, where transit demand was already high. The first two subway lines built in São Paulo basically followed the path of old railways and tramways, thus meeting the existing demand for travel, rather than inducing urban development or densification.

The results reinforce the importance of timing in city planning. The built environment has a high degree of inertia and changing it involves a large volume of resources and a number of inconveniences for residents. Ex-ante guiding of the development and growth of cities is undoubtedly cheaper than ex-post solving of urban problems; but such an approach is highly complex in a city experiencing rapid growth with scarce resources. The results point to the need to integrate transport policies and urban development in growing cities and highlight the central role that transport can play in inducing urban development. They do not, however, tell us how to do it. 


\section{References}

Angrist, J. D., \& Pischke, J. S. (2008). Mostly harmless econometrics: An empiricist's companion. Princeton, NJ: Princeton University Press.

Badoe, D. A., \& Miller, E. J. (2000). Transportation-land-use interaction: Empirical findings in North America, and their implications for modeling. Transportation Research Part D: Transport and Environment, 5(4), 235-263.

Baum-Snow, N. (2007). Did highways cause suburbanization? The Quarterly Journal of Economics, 122(2), 775-805.

Beck, N., \& Katz, J. N. (1995). What to do (and not to do) with time-series cross-section data. The American Political Science Review, 89(3), 634-647.

Boarnet, M. G., \& Haughwout, A. F. (2000). Do highways matter? Evidence and policy implications of highways' influence on metropolitan development. Washington, DC: Brookings Institute Center on Urban and Metropolitan Policy.

Bonduki, N. G., \& Rolnik, R. (1979). Periferias: Ocupação do espaço e reprodução da força de trabalho. São Paulo: FAU-USP/Fundação para Pesquisa Ambiental.

Caldeira, T. P. R. (2000). City of walls: Crime, segregation and citizenship in Sao Paulo. Berkeley, CA: University of California.

Capoccia, G. (2016). Critical junctures. In O. Fioretos, T. G. Falleti, \& A. Sheingate (Eds.), The Oxford handbook of historical institutionalism (pp. 1-22). Oxford, UK: Oxford University Press.

Cervero, R., \& Hansen, M. (2002). Induced travel demand and induced road investment: A simultaneous equation analysis. Journal of Transport Economics and Policy, 36(3), 469-490.

Cervero, R., \& Seskin, S. (1995). An evaluation of the relationships between transit and urban form. Washington, DC: Transit Cooperative Research Program, Transportation Research Board.

Debrezion, G., Pels, E., \& Rietveld, P. (2007). The impact of railway stations on residential and commercial property value: A meta-analysis. Journal of Real Estate Finance and Economics, 35(2), 161-180.

Eletropaulo. (1986a). Bondes, terrenos e especulação. São Paulo: Cadernos História e Energia, 1.

Eletropaulo. (1986b). O Metrô da light. São Paulo: Cadernos História e Energia, 8.

EMPLASA. (2002). Expansão da area urbana da regiáo metropolitana de São Paulo - Relatório de pesquisa. São Paulo: EMPLASA.

Fulton, L. M., Noland, R. B., Meszler, D. J., \& Thomas, J. V. (2000). A statistical analysis of induced travel effects in the U.S. Mid-Atlantic Region. Journal of Transportation Statistics, 3(1), 1-14.

Giesbrecht, R. M. (2001). Um dia o trem passou por aqui: A história e as estórias dos trens de passageiros no Estado de Sáo Paulo e as saudades que eles deixaram. São Paulo: Studio Quadro.

Giesbrecht, R. M. (2018). Estaçôes ferroviárias do Brasil. Retrieved from http://www.estacoesferroviarias.com.br

Giuliano, G. (2004). Land-use impacts of transportation investments: Highways and transit. In S. Hanson (Ed), The geography of urban transportation (pp. 237-273). New York: Guildford Press.

Glaeser, E., \& Ponzetto, G. (2017). The political economy of transportation investment. Economics of Transportation, 13, 4-26.

Granger, C. W. J. (1969), Investigating causal relations by econometric models and cross spectral methods. Econometrics, 35, 224-238.

Guerra, E. (2014). Mexico City's suburban land use and transit connection: The effects of the Line B Metro expansion, Transport Policy, 32, 105-114.

Huang, H. (1996). The land-use impacts of urban rail transit systems. Journal of Planning Literature, 11(1), 17-30. 
Kako, I. S. (2013). O papel dos trilhos na estruturação territorial da cidade de São Paulo de 1867 a 1930. São Paulo: Universidade de São Paulo.

Kasraian, D., Maat, K., Stead, D., \& van Wee, B. (2016). Long-term impacts of transport infrastructure networks on land-use change: An international review of empirical studies. Transport Reviews, 36(6), 772-792.

King, D. (2011). Developing densely: Estimating the effect of subway growth on New York City land uses. Journal of Transport and Land Use, 4(2), 19-32.

Knight, R., \& Trygg, L. (1977). Evidence of land-use impacts of rapid transit systems. Transportation, 6(3), 231-247.

Kowarick, L., \& Frúgoli, H. (2016). Pluralidade urbana em São Paulo. São Paulo: Editora 34, Fapesp.

Langenbuch, J. (1971). A estruturação da grande São Paulo: Estudo de geografia urbana. Rio de Janeiro: Fundação IBGE.

Levinson, D. (2008a). Density and dispersion: The co-development of land use and rail in London. Journal of Economic Geography, 8, 55-77.

Levinson, D. (2008b). The orderliness hypothesis: The correlation of rail and housing development in London. Journal of Transport History, 29(1), 98-114.

Lisbôa, L. (2019). Transporte de Londres, Paris e São Paulo: Aspectos fundamentais do planejamento e expansão das redes de transporte estruturais e sua relação com a organização do tecido urbano. São Paulo: Universidade de São Paulo.

Martínez, L. M., \& Viegas, J. M. (2009). Effects of transportation accessibility on residential property values: A hedonic price model in the Lisbon metropolitan area. Transportation Research Record, 2115, 127-137.

McMillen, D., \& McDonald, J. (2004). Reaction of house prices to a new rapid transit line: Chicago's Midway Line, 1983-1999. Real Estate Economics, 32(3), 463-486.

Mendes, D. de P. S. (1992). Bonde ou luz? Eis a questäo: A crise existencial da Light no começo dos anos 30. Memória. São Paulo: Eletropaulo, 13.

Metrô. (1977). Pesquisa de Mobilidade da Região Metropolitana de São Paulo 1977: síntese das informaçoes (Pesquisa Domiciliar).

Metrô. (1987). Pesquisa de Mobilidade da Regiáo Metropolitana de São Paulo 1987: síntese das informaçoes (Pesquisa Domiciliar).

Metrô. (1999). Pesquisa de Mobilidade da Região Metropolitana de São Paulo 1997: síntese das informaçoes (Pesquisa Domiciliar).

Metrô. (2008). Pesquisa de Mobilidade da Regiáo Metropolitana de São Paulo 2007: síntese das informaçoes (Pesquisa Domiciliar).

Metrô. (2019). Pesquisa de Mobilidade da Região Metropolitana de São Paulo 2017: síntese das informaçoes (Pesquisa Domiciliar).

Mohammad, S., Graham, D., Melo, P., \& Anderson, R. (2013). A meta-analysis of the impact of rail projects on land and property values. Transportation Research Part A: Policy and Practice, 50, $158-170$.

Muller, P. (2004). Transportation and urban form - Stages in the spatial evolution of the American metropolis. In S. Hanson (Ed), The geography of urban transportation (pp. 59-85). New York: Guildford Press.

Rodríguez, D., \& Mojica, C. (2009). Capitalization of BRT network expansions effects into prices of non-expansion areas. Transportation Research Part A, 43, 560-571.

Rolnik, R. (1995). The city and the law: Legislation, urban policy and territories in the city of Säo Paulo (1886-1936). New York: New York University. 
Ryan, S. (1999). Property values and transportation facilities: Finding the transportation-land use connection. Journal of Planning Literature, 13(4), 412-427.

Silva, A. (2015). Tudo é passageiro: Expansão urbana, transporte público e o exterminio dos bondes em São Paulo. São Paulo: Annablume.

Somekh, N. (2014). A cidade vertical e o urbanismo modernizador. São Paulo: Editora Mackenzie.

Stiel, W. C. (1978). História dos transportes coletivos em São Paulo. São Paulo: McGraw-Hill do Brasil, Ed. da Universidade de São Paulo.

United Nations. (2019). World urbanization prospects: The 2018 revision (ST/ESA/SER.A/366). New York: United Nations, Department of Economic and Social Affairs, Population Division.

Velze, R. (1968). Os transportes coletivos em São Paulo. In O. Pimentel \& J. F. Marcondes (Eds.), São Paulo: Espirito, povo instituiçóes. São Paulo: Pioneira Editora.

Vitte, C., \& Imaeda, R. (2007). Transportes coletivos e urbanização na cidade de São Paulo na primeira metade do século XX: Aspectos políticos-institucionais, atores, alianças e interesses. GEOUSP - Espaço e Tempo, 21, 67-84.

Warner, S. B. (1978). Streetcar suburbs: The process of growth in Boston, 1870-1900. Cambridge, MA: Harvard University Press.

Xie, F. \& Levinson, D. (2010). How streetcars shaped suburbanization: A Granger causality analysis of land use and transit in the Twin Cities. Journal of Economic Geography, 10(3), 453-470.

\section{Appendices}

Appendices available at https://www.jtlu.org/index.php/jtlu/article/view/1969. 